\title{
Existence of service consumption service paid in sociological perspective
}

\author{
Misdela Firma Sari ${ }^{1}$, Fatmariza ${ }^{2}$, Maria Montessori ${ }^{3}$ \\ ${ }^{123}$ Universitas Negeri Padang, Padang - Indonesia, (misdelafs2@gmail.com)
}

\begin{abstract}
The purpose of this article is to explain the existence of paid consumption services in the midst of people's lives. This research uses qualitative research approach with descriptive type. Researchers found that the presence of paid consumption services in the midst of people's lives is considered very effective and efficient in terms of time and energy, this is considering the many people who live wander for both education and work. However, indirectly, the presence of paid consumption services fades the social values, the sincerity in work and the spirit of mutual cooperation begins to fade and turn into a wage system that is like making the consumption and serving the guests by way of being hired. On the other hand it also affects kinship relations.
\end{abstract}

Keywords: paid consumption services, "bagorak", social changes, change values

\section{Introduction}

The purpose of this study is to reveal the existence of paid consumption services in the midst of people's lives, the factors driving the payments of paid services and the effects of changes that occur after switching to use of paid services. People always experience the name change. There is no society that does not change, even at the smallest level. Changes can include both narrow and broad aspects. A narrow aspect may include aspects of the individual's behavior and mindset. The broad aspect can be a change in ting at the structure of society will be able to influence the development of society in the future (Martono,2011: 1).

In the community in Nagari Tujuah Koto Talago also experienced a name change. Changes that have taken place in the community since the switch to using paid services. Paid-cost service is a group that sells services to help the process of making consumption and guest services during the reception.

Prior to the presence of paid consumption services, the community in Nagari Tujuah Koto Talago made the process of making consumption in mutual way and serving the guests became the task of close relatives. Community self half is a habit of hereditary and has been entrenched in rural communities.

Now with the presence of paid consumer services the community uses it and starts waning spirit of mutual cooperation. Service paid service consumption is different from catering organized by 
companies or restaurants, paid service consumption only sell services with capitalize cooking skills conducted by small groups in the midst of rural society.

Usually upper class people who use catering but now middle class society can also use catering like the urban community although catering different versions. Rural people, especially in NagariTujuah Koto Talago have begun to imitate the life of modern society such as in the city by using groups of paid consumption services at the reception

The wage system typically occurs only in heterogeneous urban populations, relationships of interest, interdependent relationships. But it began to penetrate into the life of rural people who tend to have close kinship relationships, the relationship is kinship.

This research is related to the research topic that the author proposed almost the same as the research conducted by previous researchers. Asmidar's research on, "Changes of Malay Traditional Malay Tradition In Bantayan Hilir Village, Batu Hampar Sub-District, RokanHilir Regency" Journal. The focus of his research on the process of implementation ethnic Melayu wedding ceremony that has changed from the previous period.

While Erniwati (2012) "Changes in Social Economic Life of Padang Suburb of Padang from Farmer to Service Sector (Kalumbuk Subdistrict, Kuranji Sub-district," focus of his research on the periphery which is now a region which is now an area of growing and developing informal sector in the form of goods production and services, thus where people initially only recognize the present livelihoods other than farmers also have jobs such as the service sector.

Relevant studies relating to changes in the social life of the service sector already exist but the difference here researches the study of social behavior change in society after switching to paid service consumption and the impact it has on people's lives, whether consciously or unconsciously

Based on this background, this research has purpose to answer research question as follows: (1) How is the paid consumption service in Nagari Tujuah Koto Talago?. (2) What are the factors driving people to use the paid consumption services in Nagari Tujauh Koto Talago?. (3) How is the impact of paid consumption services on the community in Nagari Tujuah Koto Talago?

\section{Method}

This research uses qualitative approach with descriptive research type. A qualitative approach is essentially observing people in their lives, interacting with them and trying to understand the language and interpretation of the world around them (Bungin, 2013: 61-65). The study was conducted in Nagari Tujuh Koto Talago located in Guguak Sub-district, Lima Puluh Kota District. Informants in this study were taken by using purposive sampling technique (purposive samples) that researchers deliberately determine who became informants according to the desired data and research objectives.

The informants consisted of 25 people consisting of groups of paid consumption services in Nagari Tujuah Koto, the people who used paid service during the reception, the people who had attended the reception using the paid consumption service, the Nagari government, and the community leaders and other societies that know the changes in people's social life after switching to paid services.

Data collection techniques used in this research are through (a) Observation, (b) In-depth interviews (c) Documentation study to complete the information obtained through direct observation and communication techniques, other data is required by study technique documentation. Data analysis is the technique of data triangulation. The data tangle is the technique of checking the validity of the data for checking or comparative purposes of the findings data. Qualitative research is said to be scientific if the validity, reliability, and objectivity conditions have been met. (Husaini and Purnomo 2006: 87). 
Data analysis technique used in this research is qualitative data analysis technique of Miles and Huberman model which there are 3 (three) stages, namely: data reduction phase, data presentation stage, and conclusion drawing stage. Data reduction, at this stage, the researcher should be able to record field data in field records, to be interpreted, or to select each relevant data with the focus of the problem under study. After Reduction of data the next step is to display data, in the form of short description, chart, relationship between categories. Information obtained through observation and interviews is compiled and organized based on the focus of the problem under study. Data verification or decision making is an advanced analysis of data reduction, and display data so that data can be concluded, and researchers still have a chance to receive input.

\section{Research Results}

Paid Services

In Nagari Tujuah Koto Talago there are 3 groups of paid consumption services, including TIGO BALEH group, Dahliam Group and Tek Ine. These three groups were commercialized. This group originally came about because of the many work to be done on bagorak. Then came the idea to form a group that specifically helps the making of consumption if there are members who will hold an event. Seeing the number of requests then the group is commercialized. In 2005 there appeared other paid service groups such as Dahliam group and Tek Ine group.

Services offered by the TIGO BALEH group consist of two parent cookies, or consumer demand, rice cookers, barbers and cleaning tables, and washing dishes. While the group Dahliam and Tek Ine only sell cooking services only, consumers only provide food ingredients or also consumers can only make money and buy food ingredients that will be cooked.

Factors Drivers Use of Paid Service Consumption

Paying group services is a new service product created by the community to assist the community in easing the work before and during the reception event. A group of paid consumption services is a group that takes advantage of the opportunities with so many requests that it becomes a group and family business.

The birth of this group of paid consumption services aims to help the people who are holding the reception. The public prefers to use paid services for reasons more practical, easier, more efficient and less troublesome. Society is more rationality in choosing and deciding in using paying services. This is influenced by the level of education in the community. Through education it is easy to accept new innovations in services in rural communities such as Nagari Tujuah Koto Talago.

Impact on the Use of Paid Consumption Services in the Tujuah Koto Talago Society

The use of paid services has an impact on the social life of the community. The implications of the use of paid services in Nagari Tujuah Koto Talago community are:

1. Social Values in Fading Communities (Giving-receiving value turns into money transactions).

The making of consumption is usually done in mutual way, in the society implanted social values such as the value of giving receive. What we give to others then in the future will also do the same thing. So at the time bagorak many of the neighbors who came to help.However, by switching to a paid consumption service, the value of giving receive begins to fade. They do not have to come back to help the neighbors in bagorak event, because later it can also be turned to paid service services. The value of giving receives begins to fade and is replaced with money transactions through the wage system. The intimacy and togetherness that occurs when the "bagorak" does not happen again, because when the neighbors come, what the neighbors will do is no more so they just come briefly just "mancogok an muko".

2. Shifting the Role of the Big Family in Marriage Events. 
Minangkabau characters who tend to work together in doing something. In accordance with the slogan, "bareksamodipikuaringansamodijinjiang" everything when done in a way together will feel light and not burdensome. Likewise will hold an event, usually involving large families to support the implementation of the event.

The marriage ceremony certainly requires a lot of manpower to help smooth the event. Relatives and neighbors around came to help. It can foster intimacy and togetherness with the karabat. Prior to the event, the extended family had come to help, even before the reception. They help start from cooking, washing dishes, serving guests. If the kitchen is done by the elders while the young (girls) clean the guest table, add dishes, and serve the guests.

The marriage ceremony certainly requires a lot of manpower to help smooth the event. Relatives and neighbors around came to help. It can foster intimacy and togetherness with the family. Prior to the event, the extended family had come to help, even before the reception. They help start from cooking, washing dishes, serving guests. If the kitchen is done by the elders while the young (girls) clean the guest table, add dishes, and serve the guests.

Conditions before the reception, all family members involved, assisted by relatives. The cohesiveness of a family is seen when there is an event or reception. Before the reception of the manufacture of consumption is done by mutual cooperation, when the reception is also done by mutual cooperation. Sumando and Pasumando also helped in the smooth running of the event. With the services of paid consumption is considered very helpful and most responsible for the comfort of the guests. So the relatives just ignore and pretend not to know the conditions during the reception. They do not want to petrify even when crowded, because it feels it is the responsibility of the group paid service, so that they just sit during the reception.

\section{Close Relatives Changed Positions Being Guests}

The role of large families in a reception event shifted and was replaced by a group of paid consumer services. This affects relations between neighbors and close relatives. In the community in Nagari Tujuah Koto Talago not all accept change, but also there are people who refuse to change it. Not all societies have a good view of the paid services. They refuse by gossiping those who use the service.

\section{Discussion}

\section{Paid Services}

Humans and society (including its culture) are constantly undergoing change in accordance with certain stages of a simple life form into a perfect (complex) form of life. Herbert Spencer said that society is the result of the development of heterogeneous groups into heterogeneous groups both the nature and the composition (Setiadi, 2011: 612).

Society grows through individual development and unification of groups. Increasing the size of the community causes the structure to expand and become more differentiated and to increase the differentiation of the functions it performs. The more complicated and complex society will bring the division of tasks and functions. The division of duties or division of labor will then lead to stratification. In society there will be social classes.

Paying services services are a group that arises because of the similarities that offer services for the preparation of events or receptions. The division of duties or functions occurs in rural communities such as Nagari Tujuah Koto Talago, so as to appear social classes in society. Classes appear people who have money. Money is not only used as a means of payment but as a friend. When going to a reception a person no longer expects help from the neighbors, but money is petrified dinai. With the money someone can hire it to a paid service group. 
The number of community orders to the group, then group members can read the situation of the market by seeing the increase of consumer service orders so that emerging ideas dikomersilkan.Kotler said product diversification is one way to improve the performance of existing businesses by identifying opportunities to add exciting business that is not related to the company's current business.

By utilizing the business opportunity is utilized by group members. They create a group that sells cooking services, with a variety of services offered in order to smooth the course of the event, so it becomes a small business group. Business mods do not need much money, all it takes is cooking skills. This will be a business opportunity for people who want to change their economy.

Robert D Putnam (in Tadjuddin Noer Efendi) in the view of economics, capital is anything that can be profitable and productive. Capital itself can be distinguished on: (1) financial capital in the form of money; (2) Physical capital in the form of buildings or goods (raw materials); and (3) human capital in the form of quality education, quality of life (health), professionalism skills. Capital as an asset through the action kolektf produce a product that has added value. However, in the process of development there is a demand for change because in reality areas that do not have the natural resources can spur economic growth karen economic support.

Before commercialized paid group services the group payment system also changed which initially only in the form of rice and there is no determination, only limited willingly. However, after the new commercialized fixed price of service usage. Paying services group also experienced the originally voluntary wage but turned into a price benchmark (economic motive). Society always strives to improve prosperity. People are starting to compete to create innovation or renewal of their use so that people are interested and use the services offered. One way with the presence of paid service consumption.

\section{Drivers of Paid Service Consumption}

Weber mentions the existence of four types of rationality that characterize human development. The four types are, firstly, traditional rationality. This rationality aims to strive for values derived from the traditions of community life. This rationality is sometimes called irrational action. Both affective rationality (affective rationality). This rationality is a type of rationality that leads to a special relationship that can not be explained outside the circle. Third, vulue-oriented rationality (valueoriented rationality). This rationality is a rationality of people who see value as a potential or a goal of life even though the goal is not real in everyday life. Fourth, instrumental rationality (instrumental rationality). This rationality is often called "action" and "tool". In this type of rationality, man not only determines the goal to be achieved, but he has rationally been able to determine the instrument (instrument) that will be used to achieve that goal. This rationality is the highest type of rationality according to Weber. (Martono, 2011: 48)

Based on the four types of rationality according to Weber, the instrumental rationality type (instrumental rationality) is more depicted in the Nagari community Tujuah Koto Talago. Because society is more rational in determining tools to achieve goals. According to Waber (in Salim, 2002) the form of rationality includes the mean (tool) being the main target as well as the ends (which includes the cultural aspect), so it can be stated that basically a great person can live with a rational mindset that exists on a set of tools owned culture that supports his life. A rational person will choose which one is most correct to achieve his goal. (Martono, 2011: 47). In order for receptions to run smoothly they use paid service consumption to achieve these goals. This is one of the reasons why paid consumption services are still active and growing in the midst of community life in Nagari VII Koto Talago.

Lauer (2003), social change is not a process that occurs by itself, but there are several factors that cause social change, including factors from within (endogenous factors) and external factors (exogenous factors) of social systems. Exogenous factors of change are factors that arise from other 
systems, cultural personality organisms that integrate with social systems, whereas endogenous changes result from a balanced internal tension between input and output among some sub-systems.

Community inhibiting factors using Paid Service Consumption in Tujuah Koto Talago are: lack of relationship with other communities. Lack of relationships with other societies cause a society to become alienated from the association of life and result in them not knowing progress. If the association is limited, there will be limitations of thought and desire to try to use paid services. They still maintain the making of consumption in mutual cooperation, although not too many neighbors who come to help.

Prejudice against new things other than values of interest, prejudice against the new will interfere with the process of social change. Every new thing comes along, there seems to be some fear from a group of people who do not want change, then a group of people try to influence the other group. This must be removed if someone will make a social change. For example, people who use paid service consumption will be gossipedin society because it is considered not in community or do not have a good relationship with the surrounding community.

The driving factors of change come from within and increase and decrease in population. People in NagariTujuah Koto Talago also like other Minang people who have a habit of wandering. The number of people who go to wander either for the benefit of education and for the sake of looking for work.

In addition to providing convenience in the process of cooking also consumers do not need to prepare rice to entertain the neighbors who come to help. They choose rationally, when using their employment services more effectively without spending much to entertain the guests. Through human education can make changes and choose rationally in making decisions

3. Impact on the Use of Paid Consumption Services in the Tujuah Koto Talago Society.

To understand the problem of complex social change it is necessary process typology. The typology can be based on the following four criteria: (1) the form of social processes that occur; (2) the result; (3) awareness of social processes among the members of the community concerned; (4) the forces that uphold the process; (5) the level of social reality in which the process takes place; and (6) the duration of the social process (Sztompka, 2008: 13).

Paying services services are present in the community. Changes that occur in society because there are forces that enforce the process, such as groups of paid consumption services. The presence of paid consumption services is able to diminish the social values and spirit of mutual cooperation that has been implanted since long time in society.

The presence of paid consumption services brings change in the midst of society in Nagari Tujuah Koto Talago. These changes have a positive and negative impact. Positive impact is a change that brings progress and benefits to society. With the presence of a paid consumption service a person can minimize expenditures by not hosting the neighbors in bagorak events. It is also more effective and efficient in terms of time and energy. In terms of time, relatives do not have to come all day long coming to help, abandoning daily activities to help relatives who are presenting a reception. In terms of energy, the host does not have to work hard to mobilize teaga neighbors and relatives in helping make consumption and serving guests at the reception.

Negative impacts by the shifting of the community using paid service consumption, interaction between communities is reduced. Familiarity between relatives and neighbors is reflected in the bagorak activity. Clever or not to associate with other people will be seen at bagorak. Someone who is not good at mingling and willing to help the neighbors who will hold the reception will be judged not in the community and will be gibeed by other people. However, the intimacy between neighbors and relatives began to fade with the use of paid consumption services. 
The value of giving and receiving is a value that has been embedded in the community since its inception. People learn by spreading goodness, doing good to people, helping others voluntarily, who in the future believes others will do the same to us. The value began to fade as people switched to using paid services. When going to an event a person can use paid services, only need to prepare materials and money to hire them. The making of the former consumption is done in mutual way but now it becomes a money transaction.

The existence of the tendency of social relations is more materialistic. Money is used as a tool to help ease someone's business. Everything is valued with money, the work of bagorak which was formerly carried out by mutual help but now uses a wage system like the people in urban areas. Indirectly the values of mutual cooperation, sincerity, voluntary help between fellow began to fade and replaced with money. Money is considered most helpful in society. The value of mutual cooperation also faded, the values of a familial nature replaced by the position of money.

In addition to fading the value of giving to receive in the midst of social life also stretch the bonds of kinship. The position of large families in preparation during the reception, taken over by paid service consumption. When holding a reception or an event, used as a time to gather with relatives. They took the time to help, long before the day $\mathrm{H}$ had arrived the family, will remain now the time diminimalisisr be, even some are only present at the reception only.

At the reception ceremony, close relatives working together help. They take turns helping, there is no such thing as a wage system. Family cohesiveness is seen during the event. When the event took place at the wife's house, the most influential sumando, they coordinated the work. Conversely, if the reception held at the husband's house, pasumandan assisted duties, such as lifting dishes, washing pring. This is done because it has a sense of having the event so that it is responsible to help the continuity of the event.

But now with the services of paid groups that provide convenience for the event organizers. All activities are usually done together but have been replaced by paid groups. Great family work only monitors what is lacking. This resulted in large families not playing a role in an event.Changes in this position on one side of the extended family no longer need to work hard to help but on the other hand the lack of sense of owning the event. It is the big families who should play a role, but with the presence of paid consumption services, it becomes less important. They come only to attend the event just like a guest.

The presence of paid consumption services is very helpful to the consumer in preparing the reception and can open a business that capitalize the cooking skills in addition to the income of the local community.

\section{Conclusions}

Paying services is a new invention for rural communities such as Nagari Tujuah Koto Talago, a catering-like group whose services are sold by small groups in the community. Factors from outside because of the process of assimilation of modern culture such as urban use catering and wages and imitated by rural communities but formed by small groups in the midst of society.

\section{Reference}

Asmidar. (2015) Perubahan tradisi perkawinan etnis melayu di desa bantayan hilir kecamatan batu hampar kabupaten rokan hilir.Jurnal.Jom FISIP Volume 2 No. 1- Februari

Blalock, H.M.(1994). Pengantar Penelitian Sosiologi. Jakarta: Raja GravindoPersada 
Effendi.T.J. (2013) Budaya gotong royong masyarakat dalam perubahan social saat ini.Jurnal Pemikiran Sosiologi Volume 2 No. 1, Mei

Erniwati. (2012). Perubahan kehidupan sosial ekonomi masyarakat pinggiran kota padang dari petani ke sektor jasa (Kelurahan Kalumbuk Kecamatan Kuranji. Tesis. Pascasarjana UNP

Damsar (2006) Sosiologi Uang. Padang: Andalas University Press.

Hortono, P dan Hunt, C. (2000). Sosiologi Jilid Edisi Keenam . Jakarta : erlangga

Iskandar (2009)MetodologiPenelitianKualitatif. Jakarta: Gaung Persada.

Lauer,R. (2003). Prespektif Tentang Perubahan Sosial. Jakarta: Rineka Cipta

Maleong, J.L. (2010). Metode Penelitian Kualitatif. Bandung:Remaja Rosdakarya

Martono, N.(2011). Sosiologi Perubahan Sosial. Jakarta: Rajawali pres

Miles, M dan Huberman, M.A (1992). Analisis Data Kualitatif. Jakarta: UI Press

Setiadi, E.M Dan Usman K. Pengantar Sosiologi Pemahaman Fakta Dan Gejala Permasalahan Sosial: Teori, Aplikasi, dan Pemecahannya. Jakarta: Kencana Prenada media Group.

Soekanto, S. (2012). Sosiologi Suatu Pengantar. Jakarta: PT Raja Grafindo Persada

Sugyono. (2010). Metodologi Penelitian Pendidikan Kuantitatif Kualitatif. Jakarta: Bumi Aksara

Sztompka, P. (2008). Sosiologi Perubahan Sosial. Jakarta: Prenada

Turner, B.S. (2012). Teori Sosial Dari Klasik Sampai Postmodern.Yogyakarta: Pustaka pelajar. 